\title{
A MISSIONARY EXPEDITION FROM ZION HILL (NUNDAH) TO TOORBUL, MORETON BAY DISTRICT, IN 1842-43: THE JOURNAL OF THE REVEREND K.W.E. SCHMIDT
}

\author{
Niel Gunson
}

Protestant missionaries in the nineteenth century were not notable for fine insights into the cultural systerns of indigenous peoples. German missionaries from various societies were amongst the most active workers in Christianization or 'civilization' schemes in Australia, but their success in establishing stations did not necessarily reflect a more enlightened approach. Rather the reverse. Such missionaries believed in an uncompromising religious order and they imposed fairly severe standards of discipline upon those who came to their stations for rations. The world of Aboriginal religion remained a closed door for them, just as their own insistence on a justifying faith and a sacrificial god remained incomprehensible to the religious understanding of the Aborigines. The reality of one system did not admit the reality of the other and there was no bridge between them.

The journals of such missionaries may not tell us a great deal about the beliefs of the Aboriginal tribes to whom they ministered but they frequently record tribal movements and occupational pursuits and material of use to ethnohistorians, demographers and other investigators. The following journal is one of a number of manuscript diaries and reports kept by the German missionaries recruited in 1837 by the Reverend Dr John Dunmore Lang to work among the Aborigines of the Moreton Bay District under the auspices of the Presbyterian Church in New South Wales. ${ }^{1}$ The mission was established two miles from Eagle Farm at Zion Hill, now the Brisbane suburb of Nundah. ${ }^{2}$ Most of the missionaries were members of Gossner's Society (Gossnerische Missionsgesellschaft), an Evangelical missionary society founded in 1836 by the Reverend J.E. Gossner, a former Roman Catholic priest dissatisfied with the missionary policy of the societies connected with the State Church of Prussia. ${ }^{3}$ Gossner had been influenced by the missionary ideals of the Moravians, who favoured the ereation of Christian industrial settlements under the leadership of an ordained pastor.

The Reverend Karl Wilhelm Edward Schmidt was the clerical leader of Gossner's men at Zion Hill, though he shared leadership of the settlement with the Reverend Christopher Eipper, trained by the Basle Missionary Society.

The mission received government support and related to the Presbyterian Church through the New South Wales Society in Aid of the German Mission to the Aborigines, an independent body consisting of Evangelical Reformed churchmen of several denominations: Presbyterians, Congregationalists and Baptists. In 1842, both because of the general economic slump and Governor Gipps' pessimistic view of the state of Aboriginal missions in the colony, there was every prospect of government support being withdrawn. In fact, after visiting the mission in March, Gipps made support conditional on the mission locating a new site well away from Brisbane.

In 1842-43 several expeditions were made by members of the mission party to neighbouring areas. In March 1842 Peter Nique and Franz August Rode itinerated in the Humpy Bong (Redcliffe) region; in April-May 1842 Eipper went to Durundur and J.G. Haussman and A.T.W. Hartenstein went to Humpy Bong and Toorbul (in the vicinity of Bribie Island); in June 1842 Schmidt visited the 'Bunya Bunya Tree

1 See Lang Papers, Box 20. Schmidt's joumal is at ff $121-42$ and is reproduced through the courtesy of the trustees of the Mitchell Library.

2 For the history of the mission see Gunson 1960-1961, Sparks 1938.

For Gossner's career see Holsten 1949, Craig 1887. 


\section{A MISSIONARY EXPEDITION}

Country' (the country around the Bunya Mountains) in the Wide Bay district; in November 1842 Eipper and Hartenstein camped with the Aborigines at Pine River; in December 1842-January 1843 Schmidt and Rode went to Toorbul (the subject of this journal); and in March-April 1843 Eipper accompanied the Commissioner of Crown Lands, Dr Stephen Simpson, to the 'larger Bunya Country along the Wide Bay River', Simpson having been directed by Gipps to report on the region with a view to settling the missionaries there. ${ }^{4}$

In Sydney a new body to administer the mission had been inaugurated at the request of Schmidt on 15 March 1842 as an arrangement with the Synod of Australia in the previous October had proved abortive. 5 The committee was representative of the same Evangelical Reformed clerics and laity who had formed the society established in 1839; the joint secretaries were Lang and the Reverend Dr Robert Ross, minister of Pitt Street Congregational Church, and members included the Baptist minister Saunders and the Congregational merchant David Jones. ${ }^{6}$ A former London Missionary Society missionary, the Reverend L.E. Threlkeld, was appointed to the committee in June 1842. The committee's objects were as follows:

1. To correspond with the Government on all matters connected with the Missicn.

2. To collect funds for the support of the Mission and to diffuse information respecting its operations, by holding public meetings and publishing such intelligence from the Mission as may interest the public in its favour.

3. To correspond with the Missionaries, to procure and to forward supplies for the Mission and to undertake the general superintendence of their interests and affairs.

The journals of the missionaries were submitted to this committee and some of the material was published by Lang.

Schmidt, the author of this journal, was a controversial figure in the mission's history. Born at Stargard in the then Prussian province of Pomerania, he graduated from the Universities of Halle and Berlin and was the first theological student to attend Gossnex's missionary seminary in Berlin. The first incident which brought unfavourable publicity to the mission took place on 21 March 1840 when some of the missionaries fired on the Aborigines. The incident was reported on $23 \mathrm{March}$ to the Commandant, Lieutenant Gorman, who called on Schmidt and requested an explanation. Schmidt submitted a written reply in which he stated that the mission gardens were so frequently raided at night that the missionaries decided to fire their guns in order to frighten [the Aborigines] and drive them away before they came close up to the watchmen to hurt them with their spears and clubs'. Schmidt stated that no injury took place for, he said, 'we learnt a few days after, that two blacks were wounded, but so slightly, that scarcely anything can be seen, and when asked how they came to their wounds, they assigned another cause'.

Schmidt next eamed criticism for appearing to conceal abuses against the Aborigines by the squatters. On his first trip to the Wide Bay district the Aboriginal guides refused to go beyond Durundur, then the limit of settlement. An extract from his published diary alleged that one of the reasons why the guides refused to go further was that about fifty or sixty Aborigines had been 'poisoned at one of the squatters' stations'. 9 Official enquiries were made inmediately and Schmidt asserted that as

4 The journals of these survey trips, except those for April-May 1842 and Schmidt's for June 1842 , are located in Lang Papers, Box 20.

5 Minute Book for the Committee for the German Mission, in Lang Papers, Box 20.

6 The Reverend John Saunders (1806-1859), minister of Bathurst Street (Baptist) Chapel was also agent for the London Missionary Society in 1838-1840.

7 In The Colonial Observer (e.g. 23 and $27 \mathrm{July} 1842,3$ and 7 December 1842). Earlier reports had been published in The Colonist.

Schmidt to Lieut. O. Gorman, 25 March 1840, quoted in Sparks 1938:26.

Quoted in Sparks 1938:87. 
early as March 1842, after returning from Sydney, he had heard from Eipper that such a rumour was spreading. He stated that he believed the authorities were already aware of the matter from other sources. 'When writing down, therefore, my journal', he told Commissioner Simpson on 14 January 1843, 'I considered it unnecessary to make a full statement of all that had come to my knowledge since the month of March, concerning that most horrid event, or even to relate it as something new, as it was not only known several months since to the respective au thorities, but also as almost every one at Moreton Bay supposed, that an investigation would take place without delay'. ${ }^{10}$ Simpson was not convinced, commenting on the report that from the conversation of Schmidt and his colleagues it was 'very evident that their disinclination to follow up the investigation, has been caused by the fear of offending the squatters generally, a circumstance that struck me even during my previous conversations with them upon this subject'. ${ }^{1}$

In July 1843 Schmidt and Eipper supported a joint report to the Sydney committee as a result of their visits to the Wide Bay district in search of a new site. The future of the mission was uncertain and Schmidt's writings, such as the following journal, reveal that he was disillusioned with the Aborigines and that his attitude to the mission was coloured by this pessimism. His wife was ill, and he had received a call to a Lutheran congregation in the United States. Schmidt did not leave the mission until the end of 1845 , then he sailed to England where he ministered to a Lutheran congregation in Paddington. Afterwards, on the recommendation of Dr Ross of the Sydney committee, who was also agent for the London Missionary Society, he served as a missionary of that society in Samoa from 1847. He was forced to resign in 1857 because, as a widower, he was seen to take too much interest in a Samoan woman in his congregation. He married the woman and they conducted a 'free school' for the children of foreign residents in Apia until his death in 1864.

Before Schmidt left Zion Hill a second party of Gossner's men arrived in 1844 and the lay missionaries decided to continue the mission while working at their own trades. Although they remained at Zion Hill they opened a branch station at Burpengary near Caboolture as a result of their northern itinerations.

Schmidt's journal reveals a degree of religious misanthropy arising from his Eurocentric pessimism, depression and general discomfort. His movements appear important while the necessary pursuits of Aboriginal life are made to appear trivial and subordinate to the missionary's progress. He makes no attempt to come to terms with the different social outlook of the Aborigires, preferring to see them as vagabonds and rascals. Yet despite his conviction of their innate depravity and boorishness it is possible to discern more human qualities in the Aboriginal response: a desire to please on the part of the Aboriginal youths wanting to be taught a prayer, an openness about the alleged theft of flour and biscuit, a spirit of integrity and independence in the face of missionary bribes, a feeling of sympathetic understanding on the part of the third guide returning to relieve the missionary of an unaccustomed burden, and the willingness of the guides to retum to the mission station although already on their way to the bunya feast in the mountains.

10 Schmidt to Simpson, 14 January 1843, quoted in Sparks 1938:37.

11 Idem. 


\section{A MISSIONARY EXPEDITION}

Journal of $W$. Schmidt during a journey to Toorbal ${ }^{12}$ made with A. Rode from the 28 th of December 1842 to the 6 th of January 1843 .

December Wedn 28. Brother Rode and myself left this morning our Station (accompagnied by 3 black men, 1 woman and 1 child, who carried our provisions,) in order to proceed to Toorbal. Having crossed both the North and South-Pine-Rivers, which have, when Ebb-tide, about 3 feet water at the crossing, places of the Natives, we encamped near the first fresh water holes, about 1 mile beyond the North-Pine-River. The Natives had very little pleasure, to make us a hut, but wished us to be content with a fire until at last, observing our dissatisfaction, they put 3 sticks together and covered them with branches.

Th. 29 After having marched about 5 miles, we met with a few women and children of the Umpie boang ${ }^{13}$ Tribe, who were encamping at a spot called 'Burrujavoiun'. Our guides, having intended to proceed to day as far as Toorbal, lost now their pleasure, to move one step farther and wished us to encamp along with those few women and children. We however declared them, that we could not consent with their plan, having no delight in staying with half a dozen of old women and children, but desired to go to Toorbal, in the expectation, to meet there with a large number of Natives.

They then promised us, that they would break up to morrow early along with the here encamping Natives, - a few men and lads besides having gone afishing, who were expected to return before night. Acceding to their proposal I wrote the English Alphabet with charcoal on a piece of Tea tree-bark, fastened to a tree and instructed 6 children. Bro. Rode kept school in the afternoon. It was grievous to us, to observe, that the children, notwithstanding their being old schollars, upon whom we have already bestowed much time and labour, had forgotten almost every thing and that neither the children nor the aduits have as yet the right idea about the reason of our following and instructing them. ${ }^{14}$ The children still think, they must be paid for their attending our instructions and we dare not venture to travel amongst them, without having rice or bread along with us, to be able, to give them at least a little as encouragement, although they have generally plenty of food themselves, and the adults suppose, we make journeys for mere pleasure's sake, or to survey the land and to feast with them upon fish and oysters etc. Poor Creatures! Our hearts break, our Souls faint on account of the great misery, in which they languish, "their God being their belly."

As for feeding the children, I shall endeavour, to act also in the bush upon the same plan, which I have followed up hitherto at our Station, to make them do, one or another little job after school, before they get their meal, that they may consider it payment, for the job, they have done and not for the instruction, they have received. This, I am convinced, is the only way, to make them active and useful.

There is also another reason for our dissatisfaction with them, observing namely, that none of the children have a blanket, although they did receive some not many months since, with the sharp waming, neither to part with them, nor to destroy them. There are now already divided amongst old and young for services rendered to us and for attending the school about 70 blankets since the month of May. But how few are seen amongst them.

A few men and lads returned in the evening from fishing. We endeavoured to speak

12 i.e. Toorbul. Eipper had visited Toorbul in August 1841. August Rode (1811-1903), who accompanied Schmidt, was more usually known as Franz. He continued to live in the district after the cessation of the mission and gave evidence before the Select Committee of the Legislative Assembly on the Native Police Force in 1861 .

13 More usually Humpy Bong in contemporary references, now Redcliffe.

14 On 5 July 1841 Schmidt wrote that he had commenced schoolkeeping and that on some days he had over twenty children round him. 
to them about spiritual things, but they could not conceive them, and as soon as I read to them some passages from the Sacred Scriptures, which I had translated with Bracefield, ${ }^{15}$ they fell asleep. Only one listened attentively a few minutes and told us, rubbing his belly, that it did good to his bowels and desired me to read more. ${ }^{16}$ He had however scarcely uttered his wish, when he like the rest, answered with snoring upon our questions. - We closed the day with the fervent prayer, that God Almighty may soon send help out of Zion, to these "fugitives and vagabonds in the earth." -

Fr. 30 It was very painful to us, that we could not prevail with them, to be silent during our morning prayer. They smoked, laughed, shewed us their teeth and tongues and did just what they liked, so that we had to commence also this day with sorrow and patience, of hope being greatly troubled in our minds, when asking us, what will become of this nation. - One even lifted up his tomahawk, against me, when I told him, to be quiet, whilst we were speaking with God.

We continued our journey accompagnied by some more Natives, so that we had a dozen of adults and 5 children about us. One left with his children for Brisbane Town.

When stopping a little while at a spot, called "Dipperenba", I kept school. In the afternoon we crossed a small river and soon after the wide Deception River. Although there was just Ebb-tide, we had likewise to strip, as yesterday, when crossing the two Pine-rivers. It is very unpleasant to wade especially through the deep mud up to the knees along the banks of the river and to be touched and bumt by the innumerable Medusa's heads. ${ }^{17}$ It took us at least 15 Minutes to cross the Deception River.

After the Natives had fished, we proceeded to a place termed "Gibunba." Also this evening we had to forbear their brutality. One of them, "Jernmy Willboang", particularly put our patience upon a trial; he simply opposed, when he along with the other bearers of our provisions should repeat a grace before their meal. Being told, that he should not get any rice, he replied in great anger, that he had no desire to eat any rice and that he would not speak with God, God being, not in the bush. He told us likewise, that he would no more speak with us, nor carry tomorrow our provisions. After a short time however he asked us for a little bread; we told him, that he should get some, if he were going, to repeat a short prayer. That he consented. This fellow is the most shocking character we have amongst the black Natives and we should never have thought of engaging him as one of our guides, if we had not preferred, rather to be annoyed by him, than that he should be troublesome to our Station and rob our gardens and houses as he has done in former days. - Before the Natives fell asleep they tuned a short mouming song over a brother of one of our guides, who died more than 9 months since. - Being very much fatigued from the great heat during the day and a long walk, we longed for a refreshing sleep, were however greatly troubled by a very small species of Flies, which made my skin blister and itch all over.

Sat 31 We arrived this afternoon at Toorbal after a rain had wettened us. We felt very tired, the Blacks having led us a round about way over large flatts covered with

15 David Bracefield or Bracewell (c.1803-1844), notable as an absconder from the penal settlement at Moreton Bay, lived for long periods with the Aborigines. Between 1839 and 1842 he was adopted by the 'Carbaraks' tribe near Wide Bay. When located in May 1842 he was 16 allowed to work for Dr Simpson but was killed while felling timber in 1844.

16 According to Professor W.E.H. Stanner, who has referred to Durmugam rubbing his belly (Stanner 1960), this is a typical expression: 'I made a special study of their notions, of the psycho-biology of it. They believe that you think with your head and your belly, that the belly is the seat of the emotions and sentiments. They will say "so and so had a good belly on him" meaning exactly what we mean by a "warm-hearted man". They use such expressions constantly, referring to the belly/bowels as the focus of emotion, often rubbing the belly

17 to emphasize "I feel it here" " (personal communication).

7 i.e. medusae or jellyfish. 


\section{A MISSIONARY EXPEDITION}

deep sand. We were deceived in our expectation, to meet here with a large number of Natives; there was only a couple present. After a little rest I instructed four children, the fifth having not yet arrived, and Br. Rode endeavoured to instruct 3 Lads, was however unsuccessful by reason of their continual laughing.

The huts at Toorbal are a little better than those they erect usually; undoubtedly because some of this Tribe are generally staying here. - "Jemmy" and some others moved off, soon after they were fed, so a few Natives, who were told to encamp on the other side of a river "Kaerwagum", which is nunning in about half a mile's distance from the place, where the huts are. There remained therefore with us but 5 men, 3 lads, 1 old woman and 5 children. - After "Jemmy" had left "Dabianco" told me, that Jemmy had stolen some of my Flour, when he had stopped behind us during the rain. I opened my bag and found to my great astonishment, that he had left of all my flour scarcely a few cups full. The other Natives dissembled to be astonished and displeased but these rascals knew all about it.

The Flies are dreadful, my whole body is itching and sore from scratching. It rained again in the evening. This being the last day of the year, we surveyed once more in general all the mercies of God received at his hand during the past 365 days and also our innumerable shortcomings and transgressions and praised the Lord our God and Saviour for these and supplicated the forgiveness of these. And looking upon the work in which we are engaged and observing no coming of the Kingdom of God even in the smallest degree we must sigh with trembling hearts and tears in our eyes, shall we spend here our strength in vain and for nought, will the Lord not have compassion on these poor Creatures. Much indeed they are degraded, having neither Idols, nor even the essential marks of human beings, given by the Apostle Paul in his Epistle to the Romans I, 19, 20. My soul faints, when I dwell on this view. -

With the prayer of the sorrowful father in the Gospel we pass therefore over from the old to the new year, having our eye of faith fixed upon the author and finisher of our faith: "Lord we believe; help our unbelief!" Mr. 9, 20. ${ }^{18}$

1843.

January Sab. 1. We assembled the children for morning and evening prayer and gave them twice religious instruction. In the interval we edified ourselves on our most holy faith from the inspired Volumes, making our New Year's requests known unto God by prayer and supplication with thanksgiving. The women went twice for oysters and once for Bongwall, ${ }^{19}$ which took them the greater part of the day and on returning they could not lose time to fill their bellies. The men went early in the morning afishing and promised, to fetch the other Blacks from the other side of the river. -

We cannot prevent them from going their own ways even on the Sabbath day, having very little authority over them in the bush and being at the same time not able to feed them.

They have especially at Toorbal abundance of food, so that it would be very easy, to procure one day's provisions on the previous day. But first of all, they never think of caring for the next day and secondly if they have got sometimes even so much food as might do for the next whole day, they have no rest until every bit is consumed, being quite as voracious as pigs. -

The men returned not before evening, without having however any fishes. There was also but one boy along with them, by whom we learnt, that there were only a few Natives on the other side of the river and 3 children, who would not come over to us, also the other Ningé Ningé Blacks having gone some time since to the Bunya

18 Correctly Mark 9, 24. Watchnight observance was common to most Evangelical missions.

${ }^{19}$ Bangwall was the local name of a root known to the Toorbul Aborigines as dangrm. See The Colonial Observer, 14 October 1841:10. 
Bunya Mountains, who were expected to return very soon. ${ }^{20}$ We resolved therefore, to remain here a few days and to engage us in instructing the children and in making some language exercises.

After the children had said their evening prayer two lads addressed me, to make them also repeat a prayer, that the devil might not approach them, whose example all the others followed. They did it of course merely by reason of imitating and perhaps even of mocking.

It was raining the former part of this day, which makes it very unpleasant, to be in the bush, as one is obliged to remain altogether in his hut. Besides this we are excessively troubled by musquitoes and flies, so that we sometimes scarcely know, what to do for uncomfortableness.

Mond. 2. Men and women went again early in the morning for food. The 5 children were instructed. The boy, who came last night from the other camp, moved off, as soon as he saw that I assembled the children for instruction. Musquitoes and flies continue to be very troublesome. - It was only this morning, when I discovered, that "Jemmy" had stolen not only almost all my flour, but also the most of my biscuit, which I had in another bag, having left me srarcely 3 days provisions. When speaking to the other Natives about and showing them the remnant, they told me, that he and two othe: young men had stolen both flour and biscuit on Saturday, when we had sheltered in the scrub during the rain and that they had baked on the other side of the river three large cakes. This shows how little these Natives may be trusted in. They knew, that those three had stolen and had neither prevented it, nor informed me about sooner than the thieves had gone and I discovered it myself. The men returned very late from fishing. We had again a thunder storm with a little rain during the night.

Tuesd. 3. Having been taken seriously ill during the night from a severe attack of a spasm in the stomach and great headach with feverish heat I could scarcely leave to day my couch, notwithstanding I felt somewhat easier. Br. Rode had therefore to instruct the children both in the forenoon and in the afternoon. Blessed be the Lord my God, that He has redeemed my life from destruction and is healing my disease. It is exceedingly painful and distressing, to be visited by sudden and serious disease in the midst of the bush, being not only deprived of remedies, but also being beyond the reach of medical attendance.

Half a dozen of men and women and 3 children arrived this morning from the other side of the river. Along with these were also the thieves. "Jemmy" the principal thief was even bold enough, to come close up to our hut and when remonstrated by Br. Rode, that he had stolen, replied in a rash manner, he had taken but very little. Rode thought advisable, not to speak any more to him, knowing him as a very troublesome and mischievous rascal, but nevertheless he annoyed $R$. so much, who was about to keep school, that the latter threatened him, whereupon he even challenged $\mathrm{Br}$. Rode, shewing him his cudgel. I also had to suffer greatly in my hut from him, although I neither spoke with him, nor even looked at him. It was particularly

According to Eipper $(1841: 4-5)$ the Aborigines of the district were subdivided into small tribes 'each of which has a certain territory allotted to it, from which they generally derive their names. Each of these tribes may number from 50 to 60 souls. On the right bank of the river are the Amity Point, Maturbine, and Moppe's tribe, who number, together, about 200; on the left are the Duke of York's tribe, the Pine River natives, the Ninge Ninge, Umpie Boang, and Yun Monday tribes, which including the mountain tribes in their neighbourhood, amount to about 400 souls. The tribes are distinguished from each other by the direction of the incisions which they make on their breasts and arms; but the fishing tribes have, from their peculiar occupation, a fleshy protuberance on the wrist to which they are often found referring to prevent their being confounded with other natives'.

Tindale includes Ninghi in his alternate names for the Jagara (Turubul speakers), located 'Brisbane River from the Cleveland district inland to the Dividing Range about Gatton; north to near Esk; at Ipswich' (Tindale 1974:169). 


\section{A MISSIONARY EXPEDITION}

grievous to us, to observe that none of the other Natives did interfere, but that some rather followed his example in mocking at us, some others at least engaged his tricks. The Lord gave us grace, that we could bear all patiently without taking any notice of him. - The Natives went again afishing and did not return before

Wedn. 4 forenoon, having caught a great many fishes. I felt a little better, although the pain had not left me altogether. I instructed the children again in the forenoon. A messenger from the Bunya district arrived in the evening, to invite the rest of the Ningé Ningé and Umpie boang Natives to the feasting upon the Bunya fruit. ${ }^{21}$ The Natives resolved therefore this evening, to proceed thither the following morning. Having intended to return this morning, we were prevented from doing so on account of the Natives having not returned from fishing on the previous evening. - I appeased a woman, who was very angry upon others, by a piece of bread. - We had some more rain to-day.

Th. 5. I felt again unwell last night, and although I was very weak, we broke up early in the morning, to return to our Station and to leave all the Blacks to proceed to the Bunya Bunya Mountains. -

We had great difficulty to procure the necessary bearers of our things. Several having promised, to go along with us and our two principal guides, changed their minds on the point of starting, so that we had to take some bundles ourselves and to march off, until at last a third followed us, who took the bundles on his head. -

We crossed this afternoon the Deception River and the other small River and reached before night the hut at "Burrujavoiun", wherein we slept the second night, the Blacks having chosen shorter paths, as they are in a great haste, to bring us home, in order to follow the others to the Bunya Country. I was very much knocked up from walking so far and fast, feeling besides very unwell, so that I longed greatly for rest. Fr. 6. After a refreshing sleep we continued our journey, crossed early in the morning both Pine Rivers and proceeded under a burning sun to a place, where we found the first fresh water about 7 miles from our Station, having walked from half past five o'clock till 12 o'clock.

There we intended to rest a few hours, and to finish our journey in the cool of the evening. We had scarcely sat down, when also Br. Rode got very ill, so that he was afraid, we might have to remain the night here. He had great head-ack and felt sick. After having vomited however and slept a few hours, he felt a little better, so that we could move on, and finish our course praising our ever blessed Redeemer with our Wives, Brethren and Sisters for all, what He had done unto us, His servants. Unto Him be commended the establishing of the work of our hands, for His is the Kingdom, and the Power and the Glory for ever and ever. Amen.

21 Feasting on the large roasted seeds of the bunya bunya (Araucaris bidwillii) took place every third year when the seed crop was plentiful. See Young 1939.

\section{BIBLIOGRAPHY}

Craig, James. John Evangelist Gossner, Religious Tract Society New Biographical Series no. 48, reprinted in Short biographies for the people..., Vol. IV, nos. 37-48. London, [1887] .

Eipper, Christopher. Statement of the origin, condition, and prospects, of the German mission to the Aborigines at Moreton Bay, conducted under the auspices of the Presbyterian Church in New South Wales. Sydney, 1841 .

Gunson, W.N. 'The Nundah missionaries', Joumal of the Royal Historical Society of Queenslend $6(3), 1960-1961: 511-538$.

Hoisten, W. Johannes Evangelista Gossner Glaube und Gemeinde. Gottingen, 1949.

Lang Papers. The Papers of John Dunmore Lang, Box 20, 1837-67. Mitchell Library, Sydney, (MS A2240).

Sparks, H.J Q Queensland's first free settlement 1838-1938. Brisbane, 1938.

Stanner, W.E.H. 'Durmugam: a Nangiomeri', in Casagrande, Joseph B. ed In the company of man New York, 1960:64-100.

Tindale, N.B. Aboriginal tribes of Australia. Canberra, 1974.

Young, H.E. 'The romance of the bunya tree', The Queensland Naturalist, 11 (1), 1939:4-14. 